\title{
Influence of Social Media on National Security: Lithuanian Academic Youth Experience
}

\author{
Dalia PRAKAPIENE் ${ }^{1}$, Romas PRAKAPAS ${ }^{2}$, Gitana DUDZEVIČIŪTE் $\dot{E}^{3}$
}

${ }_{1,3}$ Department of Management, The General Jonas Žemaitis Military Academy of Lithuania, Šilo g. 5A, LT-10322, Vilnius

${ }^{2}$ Institute of Educational Sciences and Social Work, Mykolas Romeris University, Ateities 20, LT08303, Vilnius

E-mails: ${ }^{1}$ dalia.prakapiene@lka.lt; ${ }^{2}$ prakapas@mruni.eu; ${ }^{3}$ gitana.dudzeviciute@lka.lt

\begin{abstract}
The articles analyses the penetration of social media through personal use into daily life and the relation of this phenomenon to national security. A survey of Lithuanian higher-school students aged 18-29 was conducted according to quantitative research methodology. Young people actively use social networks for various purposes (personal, learning, work, recreation). Statistically, each individual, aged 18-29, has personal profiles on four social networking sites, yet most often does not adequately evaluate and link the use of social networks with possible national security threats and risk factors. Less than two-thirds of young people have heard something of possible threats and risk factors; however, the impact of social media on national security is not considered significant. Thus, it seems that young people lack information about real threats presented by social networks to both personal data storage and national security. no more than 600 symbols with spaces (approximately 100 words).
\end{abstract}

KEY WORDS: Social Media; National Security; Academic Youth, Generation Z

\section{Introduction}

The spread and penetration of social media into everyday life are perceived as self-evident and natural phenomena. Generation Z is often identified with mobile technology, which, according to Ozkan \& Solmaz [12], they use to interact with each other, maintain social relationships, etc. On the other hand, Facebook, Twitter, Instagram, etc. have become the inseparable elements of everyday social contacts for the representatives of previous generations, too. As Conti and Passarella [3] point out, today's media world is in close contact with the real model of human social behaviour. Such a close interaction between real and virtual worlds that helps solve everyday problems is often seen as a given that makes not only personal but also public life (e.g., e-government [6], business world [7], tourism [11] easier. However, despite these advantages, social media users irresponsibly use personal information, revealing it not only to friends or family members but also to other social network users [14]. Such, at first glance, innocent personal information display creates preconditions for a potential violation of privacy. As Thompson, McGill \& Wang [15] point out, personal computer users are among the most vulnerable because of information security threats, as individuals often lack knowledge of technology as well as consequences of its use and have no ability to identify threats.

The problem of the research is to see how social media through personal use are related to national security. The object of the research is the impact of social media on national security. The purpose of the research is to reveal the impact of social media on national security.

\section{Research Method}

The research was modelled on the methodological approaches of quantitative research. The cross-sectional design model [5] was used to carry it out as it is the most commonly used one for research in a particular group. The construct of the research instrument was designed on the basis of theoretical considerations of the analysis of social networks [13]. The choice of the research model was conditioned by the peculiarities of the analysed phenomenon - as Carolan [2] notes, in the case of social network analysis, it often involves both the method and the theory, thus combining the aforementioned theoretical considerations of social network analysis and combining them with social constructivism [1] and knowledge management [9]. A questionnaire survey method was chosen for the empirical research. Indicators of measurement of the instrument used in the research were selected based on the meta-analysis data of scientific sources and the specific context of the legal environment characterizing the situation in Lithuania [10]: national security interests, contribution of conscious citizens to the development of the country's security and prosperity, information and cyber threats, etc. Young people (18-29 years old) born and / or raised in the digital age of Generation Z [4] and studying in different 
Lithuanian higher education institutions (Vilnius, Kaunas, Klaipeda)) were interviewed for the research. The subjects were selected by simple random sampling $\left(n=152^{4}\right)$. The research involved $32.24 \%$ men and $67.76 \%$ women, $51.97 \%$ of the participants were studying at universities and $48.03 \%$ at non-university higher education institutions at the time of the research. It was conducted in March and April, 2018. Descriptive and inferential statistical research methods were used to analyse the collected data using SPSS 22 software package.

\section{Research Results}

Research data shows that young people (aged 18-29), who were born and / or raised in the digital age of Generation $\mathrm{Z}$, enjoy a wide range of social media benefits - most often social networks are necessary for them to communicate with their friends $(95.39 \%)$, to search for information $(84.87 \%)$ and spend leisure time $(81.58 \%)$, for studies $(66.45 \%)$, to communicate with family members $(66.45 \%)$ and share photos $(50.66 \%)$, for work (or business) $(44.08 \%)$ and discussions $(35.53 \%)$, to share experience (25.00\%) and videos (19.74\%), to look for new friends (15.79\%) and play games $(10.53 \%)$. The results are presented in the Table 1.

The purposes of using social media (\%)

Table 1

\begin{tabular}{|l|l|l|l|}
\hline \multicolumn{1}{|c|}{ The purposes of using social media } & \multicolumn{1}{c|}{ Most often } & \multicolumn{1}{c|}{ Neast often } & \multicolumn{1}{c|}{ Ner } \\
\hline Searching for information & 84.87 & 13.16 & 267 \\
\hline Games & 10.53 & 62.50 & 1.97 \\
\hline Leisure & 81.58 & 16.45 & 7.89 \\
\hline Learning (studies) & 66.45 & 25.66 & 21.71 \\
\hline Work (business) & 44.08 & 34.21 & 0.66 \\
\hline Communication with friends & 95.39 & 3.95 & 6.58 \\
\hline Communication with relatives & 66.45 & 26.97 & 32.89 \\
\hline Searching for new friends & 15.79 & 51.32 & 13.82 \\
\hline Discussion (sharing opinions) & 35.53 & 50.66 & 17.11 \\
\hline Sharing videos & 19.74 & 63.16 & 8.55 \\
\hline Sharing photos & 50.66 & 40.79 & 17.11 \\
\hline Sharing experiences & 25.00 & 57.89 & \\
\hline
\end{tabular}

Research data shows that the prioritization of some goals is related to gender (e.g., communication with family members, $r=-0.246, p<0.005$ ) or age (e.g., communication with friends, $r=0.281, p<0.001)$. On average, young people use four social networks $(\mathrm{M}=3.6)$, the most popular (see Fig. 1) of which are Facebook (98.68\%), Youtube (93.42\%), Instagram $(73.03 \%)$, Google+ (43.42\%).

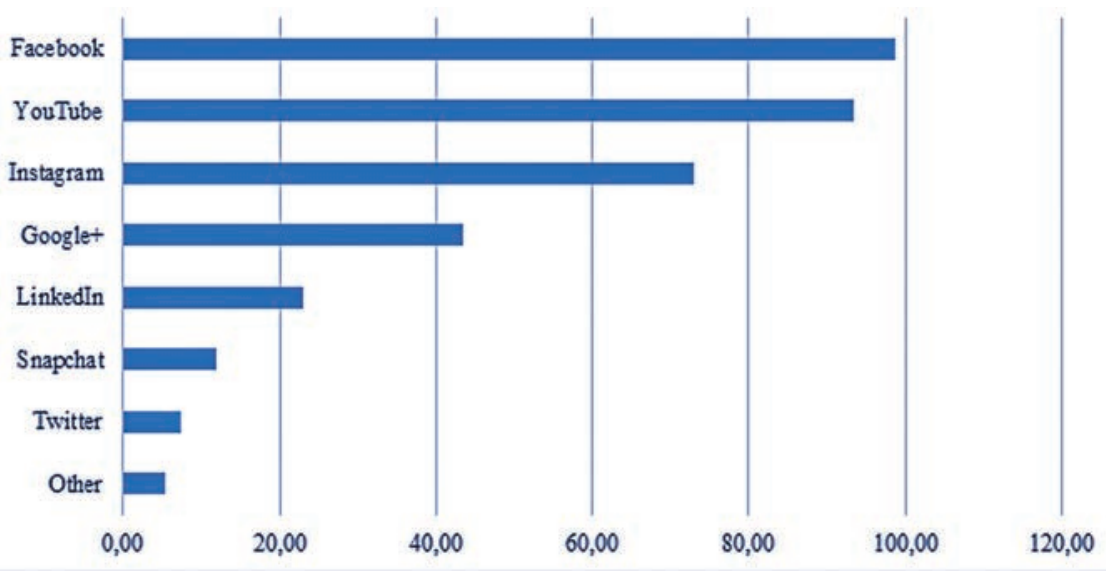

Fig. 1. The popularity of using social media (\%)

Almost all young people (95.39\%) who participated in the research have indicated their real name and post their personal photos $(90.79 \%$ ) on social networks (see Fig. 2).

4 Limitations of the research - the generalization of findings due to a relatively small sample of research is not possible; the results of the research show only a trend. 


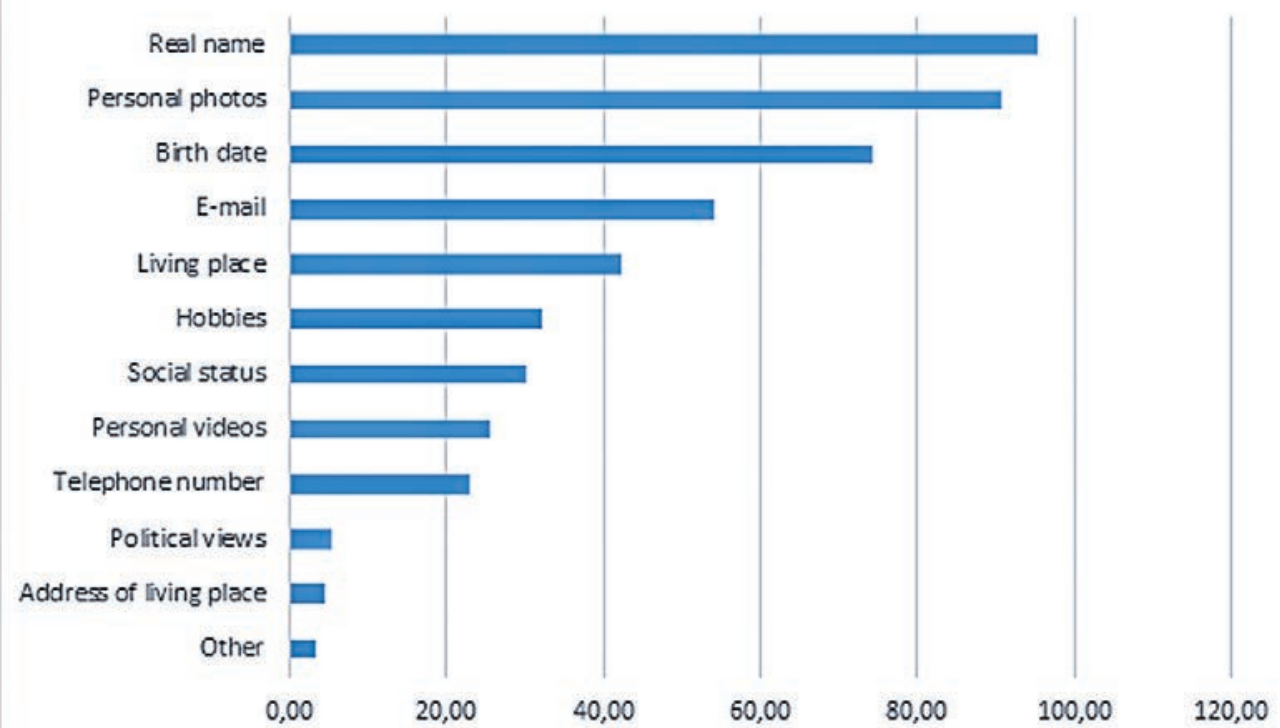

Fig. 2. Frequency of publishing personal information on social networks (\%)

Also, most social network users have provided their exact birth date (74.34\%) and email address (53.95\%). One third has indicated their interests, a place of residence as well as a social status; a quarter has published their personal telephone number. $4.61 \%$ of the participants indicated that they have provided the exact address of their place of residence. Almost all young people connect to their social networking accounts with smartphones $(99.34 \%)$ or personal computers $(65.13 \%)$. A significant proportion $(14.47 \%)$, however, regardless of any security requirements, uses public facilities in their education or work institutions. It turned out that only $48.03 \%$ of all the participants while connecting to social networks pay attention to the security of public and unprotected networks. Half of them refrain from joining such networks and the rest rely on their connection passwords. $94.74 \%$ use a password to protect their personal profile, the rest state that it is not necessary when using a personal device that only he/she alone uses.

Table 2

Awareness of threats, dangers and risk factors to national security (respondents' opinion, \%)

\begin{tabular}{|c|c|c|c|}
\hline Threats, dangers and risks to national security & Aware & Have heard & $\begin{array}{l}\text { Unaware/ do not have } \\
\text { an opinion }\end{array}$ \\
\hline Conventional military threats & 25.00 & 33.55 & 41.45 \\
\hline Disguised military and intelligence tools & 27.63 & 40.13 & 32.24 \\
\hline Threats to the unity of the Euro-Atlantic community & 21.71 & 19.08 & 59.21 \\
\hline Instability in the region and in the world & 38.82 & 38.16 & 23.03 \\
\hline Terrorism, extremism, radicalization & 59.21 & 27.63 & 13.16 \\
\hline Information threats & 67.11 & 21.71 & 11.18 \\
\hline Cyber threats & 63.16 & 25.00 & 11.84 \\
\hline Economic and energy dependence, economic vulnerability & 36.18 & 28.29 & 35.53 \\
\hline $\begin{array}{l}\text { The development of unsafe nuclear energy near the borders of } \\
\text { the Republic of Lithuania }\end{array}$ & 41.45 & 25.66 & 32.89 \\
\hline Social and regional exclusion, poverty & 55.26 & 23.03 & 21.71 \\
\hline Demographic crisis & 49.34 & 25.66 & 25.00 \\
\hline Corruption & 64.47 & 21.71 & 13.82 \\
\hline Organized crime & 52.63 & 33.55 & 13.82 \\
\hline National and international levels extreme situations & 36.18 & 36.84 & 26.97 \\
\hline Crisis of values & 37.50 & 28.29 & 34.21 \\
\hline
\end{tabular}

A much more problematic situation emerges when a stranger sends a friend request $-2.63 \%$ accept all requests and $38.82 \%$ do that sometimes. The magnitude of the problem is highlighted by the fact that only more than half of all participants have heard about some of national security threats and risk factors (see Table $2 ; 67.11 \%$ have heard of information threats, $64.47 \%$ of corruption, $63.16 \%$ of cyber-terrorism, $59.21 \%$ of terrorism, $55.26 \%$ of social exclusion, poverty, etc.). 
Awareness of national security threats dangers and risks factors (Mann-Whitney Test by gender)

\begin{tabular}{|c|c|c|c|c|}
\hline Threats & Gender & Mean Rank & Sum of Ranks & Asymp. Sig. \\
\hline \multirow{2}{*}{ Conventional military threats } & Male & 62.21 & 3048.50 & \multirow{2}{*}{0.004} \\
\hline & Female & 83.30 & 8579.50 & \\
\hline \multirow{2}{*}{ Disguised military and intelligence tools } & Male & 65.42 & 3205.50 & \multirow{2}{*}{0.025} \\
\hline & Female & 81.77 & 8422.50 & \\
\hline \multirow{2}{*}{$\begin{array}{l}\text { Threats to the unity of the Euro-Atlantic } \\
\text { community }\end{array}$} & Male & 66.88 & 3277.00 & \multirow{2}{*}{0.042} \\
\hline & Female & 81.08 & 8351.00 & \\
\hline \multirow{2}{*}{ Cyber threats } & Male & 63.77 & 3124.50 & \multirow{2}{*}{0.01} \\
\hline & Female & 82.56 & 8503.50 & \\
\hline \multirow{2}{*}{$\begin{array}{l}\text { Economic and energy dependence, economic } \\
\text { vulnerability }\end{array}$} & Male & 64.00 & 3136.00 & \multirow{2}{*}{0.012} \\
\hline & Female & 82.45 & 8492.00 & \\
\hline \multirow{2}{*}{$\begin{array}{l}\text { The development of unsafe nuclear energy near the } \\
\text { borders of the Republic of Lithuania }\end{array}$} & Male & 61.51 & 3014.00 & \multirow{2}{*}{0.003} \\
\hline & Female & 83.63 & 8614.00 & \\
\hline
\end{tabular}

The findings of the Mann-Whitney test show that women know about the identified national security threats and risk factors statistically better than males $(p<0.05)$; in terms of educational institutions, college students know about the threats statistically better than university students $(p<0.03)$. The results are presented in the Table 3 . Of all the participants in the research who have heard something of possible threats to national security and risk factors only $74.34 \%$ associate the spread of information threats and $65.79 \%$ of cyber threats with the use of social networks.

Awareness of national security threats dangers and risks factors

Table 4 (Mann-Whitney Test by study institution)

\begin{tabular}{|c|c|c|c|c|}
\hline Threats & Institution & Mean Rank & $\begin{array}{l}\text { Sum of } \\
\text { Ranks }\end{array}$ & Asymp. Sig. \\
\hline \multirow{2}{*}{ Disguised military and intelligence tools } & University & 64.88 & 5125.50 & \multirow{2}{*}{0.000} \\
\hline & College & 89.08 & 6502.50 & \\
\hline \multirow{2}{*}{ Threats to the unity of the Euro-Atlantic community } & University & 67.79 & 5355.50 & \multirow{2}{*}{0.005} \\
\hline & College & 85.92 & 6272.50 & \\
\hline \multirow{2}{*}{ Instability in the region and in the world } & University & 66.35 & 5241.50 & \multirow{2}{*}{0.002} \\
\hline & College & 87.49 & 6386.50 & \\
\hline \multirow{2}{*}{ Information threats } & University & 69.32 & 5476.50 & \multirow{2}{*}{0.027} \\
\hline & College & 84.27 & 6151.50 & \\
\hline \multirow{2}{*}{ Cyber threats } & University & 68.59 & 5418.50 & \multirow{2}{*}{0.016} \\
\hline & College & 85.06 & 6209.50 & \\
\hline \multirow{2}{*}{$\begin{array}{l}\text { Economic and energy dependence, economic } \\
\text { vulnerability }\end{array}$} & University & 67.47 & 5330.00 & \multirow{2}{*}{0.006} \\
\hline & College & 86.27 & 6298.00 & \\
\hline \multirow{2}{*}{$\begin{array}{l}\text { The development of unsafe nuclear energy near the } \\
\text { borders of the Republic of Lithuania }\end{array}$} & University & 66.09 & 5221.00 & \multirow{2}{*}{0.002} \\
\hline & College & 87.77 & 6407.00 & \\
\hline \multirow{2}{*}{ Social and regional exclusion, poverty } & University & 64.85 & 5123.50 & \multirow{2}{*}{0.000} \\
\hline & College & 89.10 & 6504.50 & \\
\hline \multirow{2}{*}{ Demographic crisis } & University & 66.30 & 5237.50 & \multirow{2}{*}{0.002} \\
\hline & College & 87.54 & 6390.50 & \\
\hline \multirow{2}{*}{ Corruption } & University & 69.64 & 5501.50 & \multirow{2}{*}{0.037} \\
\hline & College & 83.92 & 6126.50 & \\
\hline
\end{tabular}

More than $60 \%$ do not see any possible links between all other national security threats and risk factors and the use of social networks. In this regard, there are no differences between male and female opinions. However, regarding educational institutions (see Table 4), the findings of the Mann-Whitney test show that college students statistically see potential links more often $(\mathrm{p}<0.01)$.

\section{Conclusions}

Young people actively use social networks for various purposes (personal, learning, work, recreation). A statistical person, aged 18-29, has personal profiles on four social networks, yet most often does not adequately evaluate and link 
the use of social networks with possible national security threats and risk factors: relatively often accepts friend requests from little-known people, posts a lot and various personal information, does not deter from using public computers and unsecured networks. Less than two-thirds of young people have heard something of possible threats and risk factors; however, the impact of social media on national security is not considered significant. Thus, it seems that young people lack information about real threats presented by social networks to both personal data storage and national security.

\section{References}

1. llen, M. The sage encyclopaedia of communication research methods. Thousand Oaks, CA: SAGE Publications Ltd, 2017.

2. Carolan, B. V. Social network analysis and education: Theory, methods \& applications. Thousand Oaks, CA: SAGE Publications Ltd, 2014.

3. Conti, M., Passarella, A. Online Social Networks and Media. Online Social Networks and Media, 2017, 1, p. iii-vi.

4. Dabija, D.-C., Babut, R., Dinu, V., Lugojan, M. I. Cross-Generational Analysis of Information Searching Based on Social Media in Romania. Transformation in Business \& Economics, 2017, 16(2), p. 248-270.

5. Edmonds, W. A., Kennedy, T. D. An Applied Guide to Research Designs: Quantitative, Qualitative, and Mixed Methods. London: SAGE Publications, Inc, 2017.

6. Gao, X., Lee, J. E-government services and social media adoption: Experience of small local governments in Nebraska state. Government Information Quarterly, 2017, 34(4), p. 627-634.

7. Grizane, T., Jurgelane, I. Social Media Impact on Business Evaluation. Procedia Computer Science, 2017, 104, p. 190-196.

8. Yasin, A., Liu, L., Li, T., Wang, J., Zowghi, D. Design and preliminary evaluation of a cyber Security Requirements Education Game (SREG). Information and Software Technology, 2018, 95, p. 179-200.

9. Mittelmann, A. Personal Knowledge Management as Basis for Successful Organizational Knowledge Management in the Digital Age. Procedia Computer Science, 2016, 99, p. 117-124.

10. Nacionalinio saugumo strategija. TAR, 2017, 1424.

11. Narangajavana, Y., Callarisa Fiol, L. J., Moliner Tena, M. Á., Rodríguez Artola, R. M., Sánchez García, J. The influence of social media in creating expectations. An empirical study for a tourist destination. Annals of Tourism Research, 2017, 65, p. 60-70.

12. Ozkan, M., Solmaz, B. Mobile Addiction of Generation Z and its Effects on their Social Lifes: (An Application among University Students in the 18-23 Age Group). Procedia - Social and Behavioral Sciences, 2015, 205, p. 92-98.

13. Prell, C. Social network analysis: history, theory \& methodology. London: Sage Publications, 2012.

14. Rathore, S., Sharma, P. K., Loia, V., Jeong, Y.-S., Park, J. H. Social network security: Issues, challenges, threats, and solutions. Information Sciences, 2017, 421, p. 43-69.

15. Thompson, N., McGill, T. J., Wang, X. "Security begins at home": Determinants of home computer and mobile device security behavior. Computers \& Security, 2017, 70, p. 376-391. 